\title{
Climate sensitivity in the northern high latitudes using the Brazilian Earth System Model
}

\section{Sensibilidade climática em altas latitudes do Hemisfério Norte usando o Modelo Brasileiro do Sistema Terrestre}

\author{
Fernanda Casagrande ${ }^{1 *}$, Paulo Nobre ${ }^{1}$, Ronald B. Souza ${ }^{1}$, André L. Marquez ${ }^{1}$, \\ Noele F. Leonardo ${ }^{2}$, Rose A.P. Freitas ${ }^{3}$, Regiane Moura ${ }^{1}$, Vinicius Capistrano ${ }^{4}$
}

\begin{abstract}
An expressive number of scientific publications including the recent IPCC-AR6 report have warned about the effects of the ongoing and the projected climate change in the northern high latitudes as response to $\mathrm{CO}_{2}$ forcing. Here we investigate the response of the Arctic region to an increase in atmospheric $\mathrm{CO}_{2}$ concentration using the Brazilian Earth System Model and other three state-of-the-art Global Climate Model from the CMIP5 project. We evaluated the Arctic climate sensitivity through the Polar amplification using two numerical experiments. Our results showed that the northern high latitudes are described as the most climatically sensitive areas of the world, with strongest warming occurring in winter (DJF) and autumn (SON). The Arctic climate sensitivity is linked to changes in sea ice extent and sea ice thickness. Considering this scenario, it is expected that the Arctic will become ice-free in summer time and covered only by first-year-sea ice in the remaining months. We suggest that the projected sea ice albedo feedback will reinforce the Arctic warming with lack of understanding effects beyond the Arctic region.
\end{abstract}

Keywords: Climate change; Polar Amplification; Climate Models; Future Scenarios; CMIP

\section{RESUMO}

Um expressivo número de publicações científicas, incluindo o recente relatório do IPCC -AR6 chama atenção para os efeitos das mudanças climáticas em altas latitudes e projeções em resposta ao forçamento de $\mathrm{CO}_{2}$. Nesse artigo investigamos o efeito do aumento de $\mathrm{CO}_{2}$ atmosférico, no Ártico, utilizando o Modelo do Sistema Terrestre Brasileiro e outros três Modelos Climáticos Globais considerados estado da arte, pertencentes ao CMIP5. Avaliamos a sensibilidade climática do Ártico através da Amplificação Polar utilizando dois experimentos numéricos. Nossos resultados indicam que as altas latitudes do hemisfério norte são as regiões climaticamente mais sensíveis no mundo, com amplificado aquecimento ocorrendo durante o inverno (DJF) e outono (SON). A sensibilidade climática no Ártico é associada a mudanças na

1 Earth System Numerical Modeling Division, National Institute for Space Research (INPE),

Cachoeira Paulista/Brazil 1. *E-mail: fe.casagrande2@gmail.com

2 Institute of Research and Nuclear Energy (IPEN), São Paulo/Brazil

3 Department of Meteorology, Pelotas Federal University (UFPEL), Pelotas/Brazil

4 Institute of Physics, Federal University of Mato Grosso do Sul (UFMS), Campo

Grande/Brazil 
extensão e espessura do gelo marinho. Considerando esse cenário, espera-se que o Ártico fique sem gelo no verão e coberto apenas pelo gelo de primeiro ano nos meses restantes. Sugerimos que o feedback projetado do albedo-gelo marinho reforçará o aquecimento no Ártico com efeitos ainda não conhecidos além das regiões Árticas.

Palavras-chave: Mudanças Climáticas; Amplificação Polar; Modelos Climáticos; Cenários Futuros; CMIP

\section{INTRODUCTION}

The climate sensitivity refers to the effects of carbon dioxide $\left(\mathrm{CO}_{2}\right)$ increases on the global temperature after the change in the climate system, for instance: the response of global mean temperature to abrupt $4 \mathrm{xCO}_{2}$ forcing (Huusko et al, 2021). Polar regions are more sensitive to climate change than the rest of the world. The Arctic is warming at a rate of almost twice of the global average over the last decades (Casagrande et al., 2020; Smith et al., 2019; Serreze \& Barry, 2011). This phenomenon is known as Arctic Amplification and is linked with changes in sea ice, cloud cover and both atmospheric and oceanic heat transport (Dai et al., 2019; Goosse et al., 2018; Serreze \& Barry 2011; Alexeev et al., 2005; Cai, 2005).

The Arctic amplification has been the central theme of several studies in recent years. Both observations and state-of-the-art Global Climate Model simulations have shown that the Arctic Amplification is an intrinsic feature of the Earth's climate system as a response to greenhouse gas (GHG) forcing (IPCC, 2021; Casagrande et al., 2020; IPCC, 2019; Overland et al., 2019; Dai et al., 2019; Stuecker et al., 2018; Screen \& Williamson, 2017; Pithan \& Mauritsen, 2014; Serreze \& Barry, 2011; Holland \& Bitz, 2003).

Previous and most recent studies, using distinct data set (observational and climate simulations) agree with the emergence of the Arctic climate change and the climate sensitivity (Casagrande et al., 2020; Overland et al. 2019; IPCC, 2019; Screen \& Williamson 2017). Bekryaev et al., (2010) using extensive observational data from meteorological stations at high northern latitudes $\left(>60^{\circ} \mathrm{N}\right)$ found a warming rate of $1.36^{\circ} \mathrm{C}$ century $^{-1}$ for the period from 1875 to 2008 . The trend is almost double that of the Northern Hemisphere trend $\left(0.79^{\circ} \mathrm{C}\right.$ century $\left.{ }^{-1}\right)$, with an accelerated warming rate in the most recent decade. Holland \& Bitz (2003) using a set of 15 state-of-the-art global climate 
models found that the range of simulated Arctic warming as response to an increase of $2 \mathrm{xCO}_{2}$ concentration varies largely between the models and it is from 1.5 to 4.5 times the global mean warming. The large bias among the models is related to differences in simulating ocean heat transport, polar cloud cover and sea ice (e.g a simulation with thinner sea ice cover obtains higher polar amplification). The previous and most recent CMIP simulation (Coupled Model Intercomparison Project, Version 5 and 6) suggested that the polar amplification will continue to intensify with effects extending beyond the Arctic region (Cai et al., 2021; Cai et al. 2021; Davy \& Outten 2020; Jung et al. 2020; Pithan \& Mauritsen 2014; Bintanja et al., 2013; Serreze \& Barry, 2011).

The way by the polar climate will change as response to an external forcing depends deeply on feedback processes, which operate to amplify or diminish the effect of climate forcing. These feedbacks depend on integrated coupled processes between ocean-atmosphere-cryosphere in a non-linear response over a large spectrum of spatial and temporal scales making the quantification more complicated (Boeke et al., 2021; IPCC, 2021; IPCC, 2019; Pithan \& Mauristsen, 2014).

The mainly intertwined feedbacks involved in the polar amplification process are: albedo-sea ice feedback (Thackeray \& Hall, 2019; Hall, 2004; Curry et al., 1995), temperature feedback (Pithan \& Mauristsen, 2014), water vapor and cloud feedback (Graversen \& Wang 2009; Vavrus, 2004) and lapse rate feedback (Boeke et al. 2021; Bintanja et al 2013). The albedo-sea ice feedback is often cited as the major contributor of the polar amplification. As temperature rises, sea ice is reduced, decreasing the surface albedo and increasing the amount of sunlight absorbed by the upper ocean. This increase in absorbed solar radiation contributes to continued and accelerated warming (Thackeray \& Hall, 2019; Curry et al., 1995). However, Graversen \& Wang (2009) found that albedosea ice feedback is a contributing, but not a dominating mechanism underlying the Arctic warming. The authors, using simulations with locked surface albedo suggested that an increase in water vapor and cloud cover lead to a greenhouse effect, which is more intense in northern high latitudes. Pithan \& Mauritsen (2014), using CMIP5 models suggested that the temperature feedback is causing more enhanced Arctic warming than albedo-sea ice feedback.

Indeed, the physical processes involved the climate sensitivity in the northern high latitudes are not necessarily independent of each other and involve complicated structures 
occurring at many scales. The combination between complexities of linked multiples processes; uncertainties of global climate models and absence of observational data sets deviate the climate projections from more realistic simulations and is still a subject of debate. Nevertheless, even with inherent limitations and uncertainties, the global climate models are the most powerful tools available for simulating the climate response to GHG forcing and to provide future scenarios to help decision makers, the governments and the community (IPCC, 2021; IPCC, 2019; O’Neill et al., 2016; Taylor et al., 2012).

Recent studies have shown the advances in the Arctic climate predictions over the last few years. The improvements include better performance for simulating sea ice conditions, clouds and energy balance (Shen et al, 2021; Shu et al. 2020; Wild, 2020; Li et al., 2020). According to Stroeve et al. (2012) and Liu et al. (2012) the future advances need to incorporate improvements in the cloud parameterization schemes since the cloud feedback is the primary source of uncertainties in the polar regions (Wei et al., 2021).

In this paper we evaluated the seasonal Arctic climate sensitivity under abrupt $4 \mathrm{xCO}_{2}$ numerical experiments and the coupled ocean-atmosphere-sea ice processes related. The results presented here are based on the Brazilian Earth System Model, Version 2.5 (BESM-OA2.5) simulations and three other Coupled General Circulation Models participating in the Coupled Model Intercomparison Project, Phase 5 (CMIP5). The main goal is to investigate the Arctic climate sensitivity through polar amplification and the coupled processes underlying the seasonal Arctic warming. This paper is organized as follows: section 2 provides a description of the climate models and experimental design[s] used in this work, focusing on the BESM-OA2.5 model description (Veiga et al., 2019; Nobre et al., 2013). Section 3 examines the seasonality of the Arctic surface warming and compares the different CMIP5 climate models for the same numerical experiment. Section 4 provides an analysis of coupled ocean-atmosphere processes and feedback mechanisms. In a final Section the results are summarized.

\section{DATA SOURCES}

\section{Numerical Design}

This study uses two CMIP5 numerical experiments: (i) piControl (pre-industrial fully-coupled control, run for a hundred of years) and abrupt $4 \mathrm{xCO}_{2}$ (as piControl but run for 150 years, following an instantaneous quadrupling of the atmospheric $\mathrm{CO}_{2}$ 
concentration). The design of both experiments follows the CMIP5 protocol described in Taylor et al. (2009; 2012).

We compared our BESM-OA2.5 polar warming results (changes in surface air temperature) with the following climate models: CCSM4 model (Community Climate System Model Version 4) from National Centre for Atmospheric Research (NCAR), described in Gent et al. (2011); GFDL-ESM2M (Earth System Model 2M), from National Oceanic and Atmospheric Administration - Geophysical Fluid Dyanmics Laboratory (GFDL), described in Delworth et al. (2006) and Griffies et al. (2011) and MPI-ESM-LR model from Max Planck Institute for Meteorology (MPI), described in Marsland et al. (2003). The comparison was made considering the same numerical experiment.

\section{Brazilian Earth System Model (BESM-OA2.5)}

The BESM-OA model has been set up at the Brazilian National Institute for Space Research (INPE) and is part of CMIP5. The model is composed of the INPE/CPTEC atmospheric general circulation model (AGCM) coupled to NOAA/GFDL's Modular Ocean Model version 4p1 (MOM4p1) oceanic general circulation model (OGCM) via GFDL's Flexible Modular System ( Bottino \& Nobre, 2015; Nobre et al., 2013; Griffies, 2009).

The INPE/CPTEC AGCM has a spectral horizontal resolution truncated at triangular wave number 62, giving an equivalent grid size of 1.8758 degrees of latitude and longitude and 28 sigma levels unevenly spaced in the vertical (i.e., T062L28). The exchanges of heat, moisture and momentum between the surface and atmosphere in INPE/CPTEC AGCM over the ocean and continents are computed differently by various physical processes that define the surface fluxes.

The ocean model MOM4p1 (Griffies, 2009) from GFDL, includes the Sea Ice Simulator (SIS), described in Winton (2000). The SIS is a dynamical model with three vertical layers (two ice and one snow), and five ice thickness categories. The elasticviscous-plastic technique of Hunke \& Dukowicz (1997) is used to calculate ice internal stresses, and the thermodynamics is a modified Semtner's three-layer scheme (Semtner, 1976). SIS calculates the concentration, thickness, temperature, brine content, and snow cover of an arbitrary number of sea ice thickness categories (including open water) as well the motion of the complete pack. Additionally, the model is responsible for 
calculating ice/ocean fluxes and communicating fluxes between the ocean and atmosphere models globally.

The MOM4p1 horizontal grid resolution is set to $1^{\circ}$ in the longitudinal direction, and in the latitudinal direction the grid spacing is $1 / 4^{\circ}$ in the tropical region $\left(10^{\circ} \mathrm{S}-10^{\circ} \mathrm{N}\right)$, decreasing uniformly to $1^{\circ}$ at $45^{\circ}$ and to $2^{\circ}$ at $90^{\circ}$ in both hemispheres. For the vertical axis, 50 levels are adopted with a $10 \mathrm{~m}$ resolution in the upper $220 \mathrm{~m}$, increasing gradually to about $370 \mathrm{~m}$ of grid spacing in deeper layers. We used FMS to coupling MOM4p1 and CPTEC/AGCM. Thus, wind stress fields are computed, using Monin-Obukhov scheme within MOM4p1, from the field 10 meters above the above the ocean surface. Adjustments were done to the Monin-Obukhov boundary layer scheme, whose parameters were tuned according to the wind fields output by the CPTEC AGCM. The AGCM receives the following two fields from the coupler: sea surface temperature (SST) and ocean albedo from ocean and sea ice models at an hourly rate (coupling time step).

\section{RESULTS AND DISCUSSION}

\section{Polar amplification}

Here we present results from BESM-OA2.5 compared with three state-of-the-art CMIP5 models, using the abrupt $4 \mathrm{xCO}_{2}$ numerical experiment to assess the seasonality of polar amplification and the coupled processes involved. The main processes linked to the polar amplification are related to changes in Surface Air Temperature (SAT), sea ice, ocean heat content and surface energy budget and are closely associated with feedback processes (Pithan \& Mauritsen 2014; Screen \& Simmonds, 2010; Serreze \& Francis, 2006).

Figure 1 shows the seasonality of the Arctic amplification (change in zonally SAT average) as simulated by BESM-OA2.5 and three other CMIP5 models. This gives us a measure of the warming difference between low and high latitudes and the Arctic climate sensitivity.

An increase in the zonal mean surface temperature at high latitudes is evident with strongest warming in winter (DJF) and Autumn (SON), which exceeds the summer warming (JJA). These results are in agreement with observational and model simulations for both present-day and abrupt $4 \mathrm{xCO}_{2}$ numerical experiment (Casagrande et al. 2020; 
Pithan \& Mauritsen 2014; Bintanja \& Linden, 2013; Serreze et al., 2009; Serreze \& Francis, 2006). BESM-OA2.5 and MPI-ESM-LR models show high climate sensitivity through the simulated enhanced warming in winter and summer, compared to the GFDLESM-LR and NCAR-CCSM4 models.

Figure 1 - Zonal mean surface temperature $\left({ }^{\circ} \mathrm{C}\right)$ for the last 30 years of quadrupling atmospheric $\mathrm{CO}_{2}$ numerical experiment compared to the last 30 years of the piControl run for the following climate models: (a) BESM-OA2.5, (b) NCAR-CCSM4, (c) GFDL-ESM-LR and (d) MPI-ESMLR. Winter time (DJF) is represented by blue lines, spring (MAM) is represented by black lines, summer $(\mathrm{JJA})$ is represented by red lines and autumn $(\mathrm{SON})$ is represented by green lines.
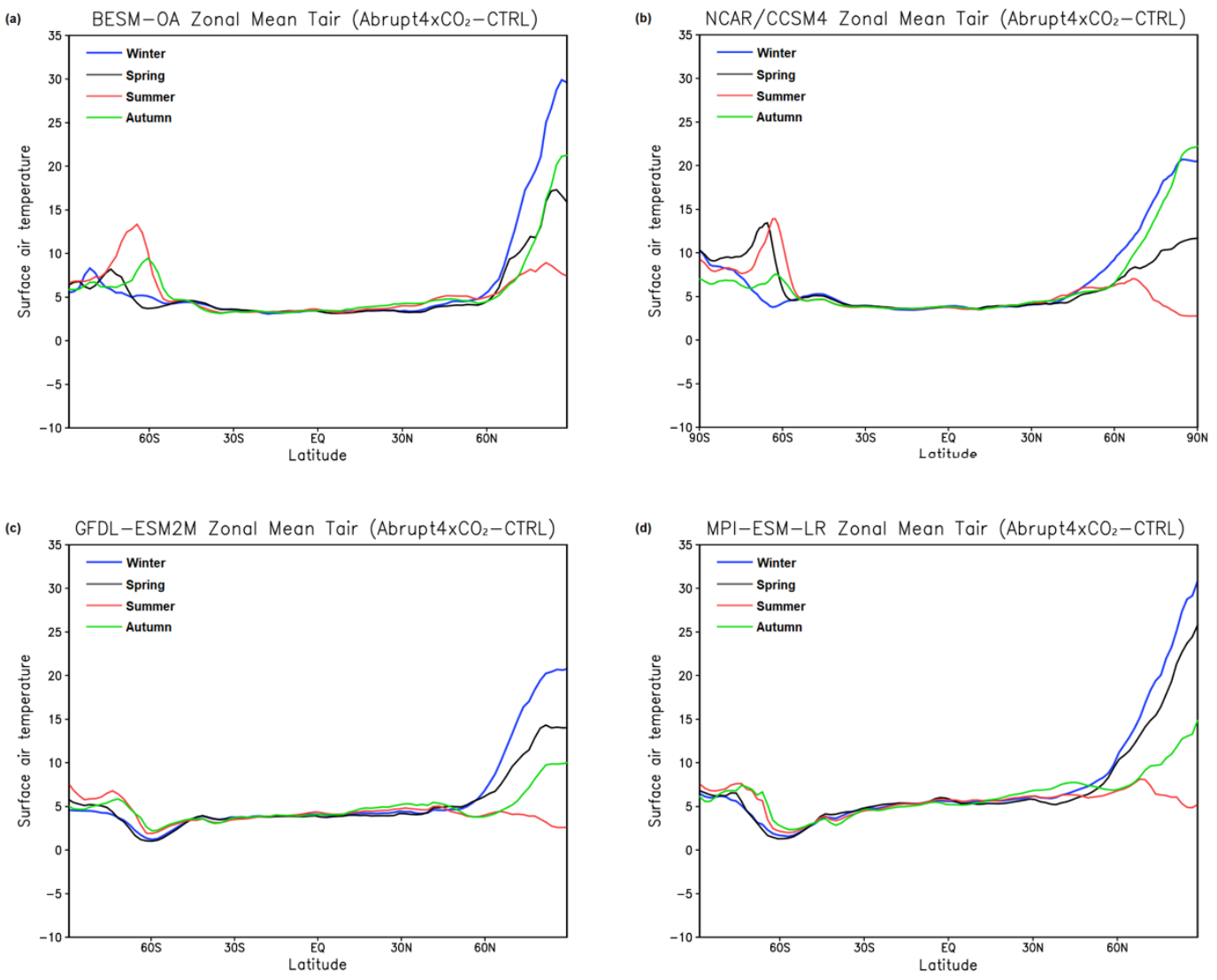

Source: authors' authorship (2021)

The comparative simulated values in winter for the Arctic polar amplification are close to $30^{\circ} \mathrm{C}$ (BESM-OA2.5 and MPI-ESM-LR) and $20^{\circ} \mathrm{C}$ (GFDL-ESM-LR and NCARCCSM4). For summer the values of the Arctic polar amplification are close to $7^{\circ} \mathrm{C}$ (BESM-OA2.5) and $3^{\circ} \mathrm{C}$ (NCAR-CCSM4). In the abrupt $4 \mathrm{xCO}_{2}$ simulations (CMIP5) presented by Pithan and Mauristsen (2014), the Arctic warming for winter (summer) is 
close to $16^{\circ} \mathrm{C}\left(6.5^{\circ} \mathrm{C}\right)$. Which indicates that all of the models overestimate the Arctic winter warming in relation to the CMIP5 ensemble mean, with more pronounced warming for both BESM-OA2.5 and MPI-ESM-LR. Holland \& Bitz (2003), using CMIP2 simulations, included the NCAR model (NCAR-CCSM2) in a separated group of models with "high" Arctic warming, i.e, high climate sensitivity to increase in $\mathrm{CO}_{2}$ forcing. According to Bintanja \& Linden (2013), the CMIP5 models' outputs tend to underestimate the Arctic winter warming and overestimate summer warming over the last decades when compared to observational data. For long-term simulations the magnitude of simulated Arctic warming winter varies considerably among CMIP5 simulations. The differences are in part related to feedback mechanisms, parameterizations, ocean heat uptake and sea ice conditions (Bintanja \& Linden, 2013).

Figure 2 shows the spatial difference of surface temperature between abrupt $4 \mathrm{xCO}_{2}$ and piControl numerical experiments, considering only the last 30 years of each simulation in BESM-OA2.5 and three other CMIP5 models. This allows the comparison of the spatial response of $\mathrm{CO}_{2}$ forcing in surface temperature from different regions of the world and the climate sensitivity.

The amplified winter warming at northern high latitudes appears as an inherent characteristic of climate models. Accessing the response of quadrupling atmospheric $\mathrm{CO}_{2}$ in polar regions, the southern high latitudes warming is modest in relation to northern high latitudes warming and is most pronounced in summer (JJA), with higher values found in the BESM-OA2.5 and GFDL-ESM-LR simulations. The delayed (accelerated) warming in the Antarctic (Arctic) as a response to an increase in GHG forcing is a consequence of anomalous advection of heat out of (into) the region by the ocean (Marshall et al., 2014). Furthermore, considering that $\mathrm{CO}_{2}$ forcing is the same for both poles, large ozone depletion only occurs in the Antarctica. Marshall et al. (2014) suggest that the initial response of Sea Surface Temperature (SST) around southern high latitudes to ozone depletion is one of cooling and only later contribute to the GHG forcing warming trend as upwelling of sub-surface warm water linked with stronger surface westerlies impacts surface properties. 
Figure 2 - Spatial difference of SAT $\left({ }^{\circ} \mathrm{C}\right)$ between the abrupt $4 \mathrm{xCO}_{2}$ and piControl numerical experiments, considering only the last 30 years of each simulation for annual and seasonal time frame. BESM-OA2.5 annual (top) and below the annual and seasonal cycle of the following models: BESM-OA2.5, NCAR-CCSM4, GFDL-ESM-LR and MPI-ESM-LR for winter (DJF), spring (MAM), summer (JJA) and autumn (SON).

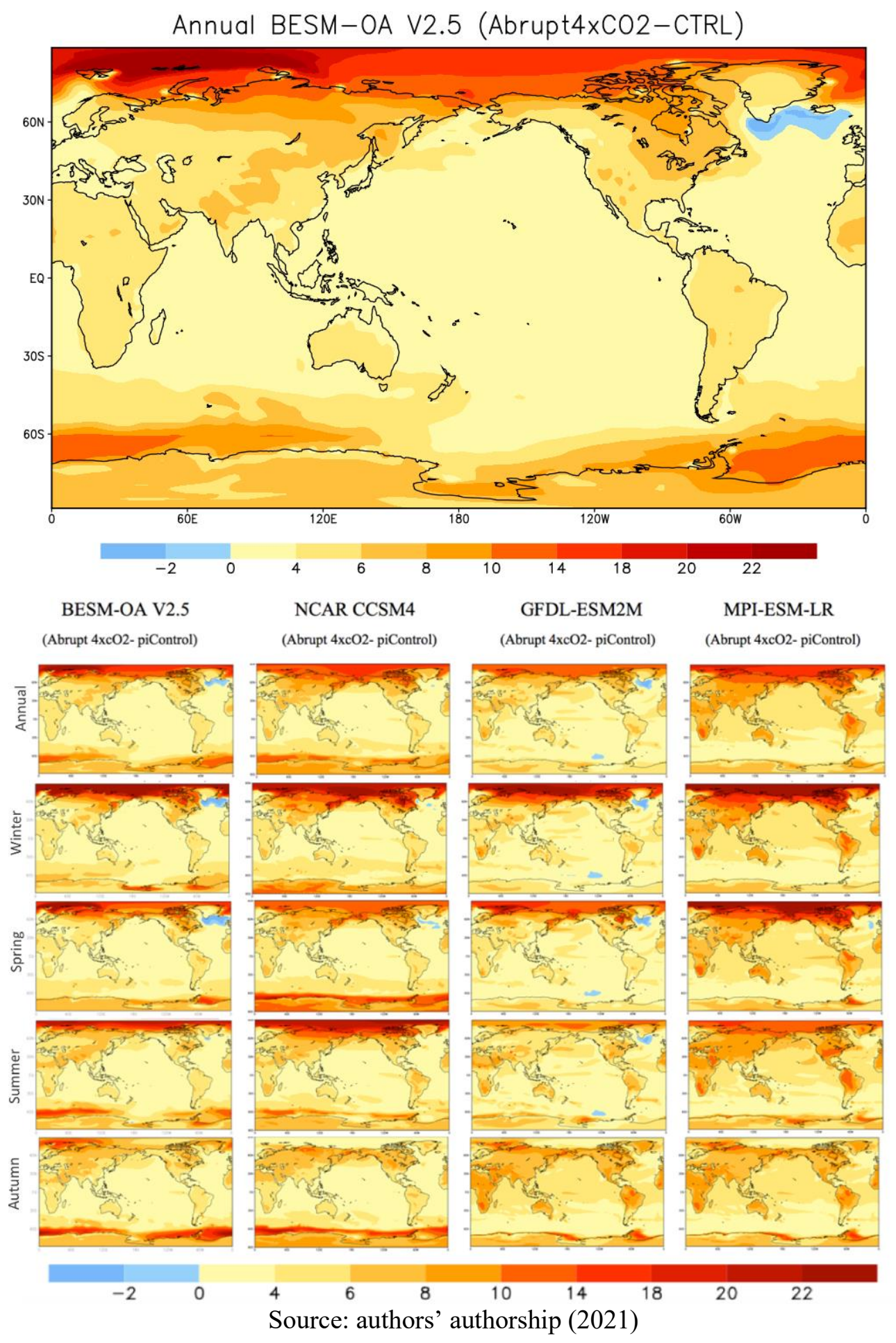


The main reason for the high Arctic climate sensitivity to increase in $\mathrm{CO}_{2}$ forcing is related to sea ice loss. According to Serreze et al. (2009), during summer the energy is used to melt sea ice and increase the sensible heat content of the upper ocean. The atmosphere loses heat to the ocean during summer whereas the flux of heat is reversed in winter. The sea ice loss in summer allows a large warming of the upper ocean but atmospheric warming is modest. The excess heat stored in the upper ocean is subsequently released to the atmosphere during winter (Serreze et al., 2009).

\section{Coupled ocean-atmosphere-sea ice processes}

The main physical processes underlying the Arctic climate sensitivity and the polar amplification will be discussed below using simulations from BESM-OA2.5. One of the main features of the Arctic Ocean is the presence of sea ice cover that isolates the atmosphere from the warmer ocean and is highly sensitive to $\mathrm{CO}_{2}$ forcing. The Arctic sea ice has decreased dramatically since 1980, faster than forecasted and unprecedented in the past 1.5 millennia (Stroeve et al., 2012; Stroeve et al., 2007).

Most of the state-of-the-art global climate models simulations have suggested that the Arctic will become ice-free in summer in approximately 30 years as response to increase in $\mathrm{CO}_{2}$ concentration. Figure 3 shows the seasonal cycle of Sea Ice Extent (SIE) and Sea Ice Thickness (SIT) over the area between $70^{\circ} \mathrm{N}$ and $90^{\circ} \mathrm{N}$, considering only the last 30 years of each simulation (piControl and abrupt $4 \mathrm{xCO}_{2}$ ). The SIE is often defined as the area of the ocean with a Sea Ice Concentration (SIC) of at least $15 \%$.

For piControl climate simulations, the mean of SIE ranges from $3 \times 10^{6} \mathrm{~km}^{2}$ to $16 \times 10^{6} \mathrm{~km}^{2}$, and the mean of SIT ranges from $0.2 \mathrm{~m}$ to $1.6 \mathrm{~m}$. Previously studies showed that BESM-OA2.5 represents quite well the seasonal cycle of Arctic SIE even with an overestimation in winter (Casagrande et al., 2016).

The growth and melting of sea ice have an important effect on the heat balance, salinity and ocean heat content. The SIT changes tend to reinforce the warming by altering the transfer of heat and moisture from the ocean to the atmosphere (Holland \& Bitz, 2003).

The response of a quadrupling of $\mathrm{CO}_{2}$ on Arctic Sea ice concentration is a sharp decrease in SIE and SIT followed by a decrease in annual amplitude, with outstanding ice-free conditions from July to October (Figure 3). The SIT has the maximum difference 
between piControl and abrupt $4 \mathrm{xCO}_{2}$ in May (close to $1 \mathrm{~m}$ ) after the winter Arctic warming. The end of the melting period (when sea ice reaches its minimum annual value) is expected for July instead of September associated with a large winter decrease in SIT and contributing to a delay in sea ice formation (in Autumn). In this scenario the Arctic Ocean will become covered only by first-year-sea ice (sea ice that does not survive to summer melt season). This thin sea ice is more vulnerable to melting away making the region more sensitive dynamically and thermodynamically to temperature changes. Furthermore, we suggest an increase in lead and polynyas (regions of open water surrounded by sea ice) that promotes a very efficient exchange of heat and moisture between the relatively warm ocean and cold atmosphere.

Figure 3 - Seasonal cycle at northern high latitudes $\left(70^{\circ} \mathrm{N}-90^{\circ} \mathrm{N}\right)$ of (a) surface air temperature $\left({ }^{\circ} \mathrm{C}\right)$, (b) albedo, (c) sea ice extent (million $\mathrm{km}^{2}$ ) and (d) Sea ice thickness (meter) for the last 30 years of the quadrupling atmospheric $\mathrm{CO}_{2}$ numerical experiment compared to the last 30 years of the piControl run, using BESM-OA2.5.
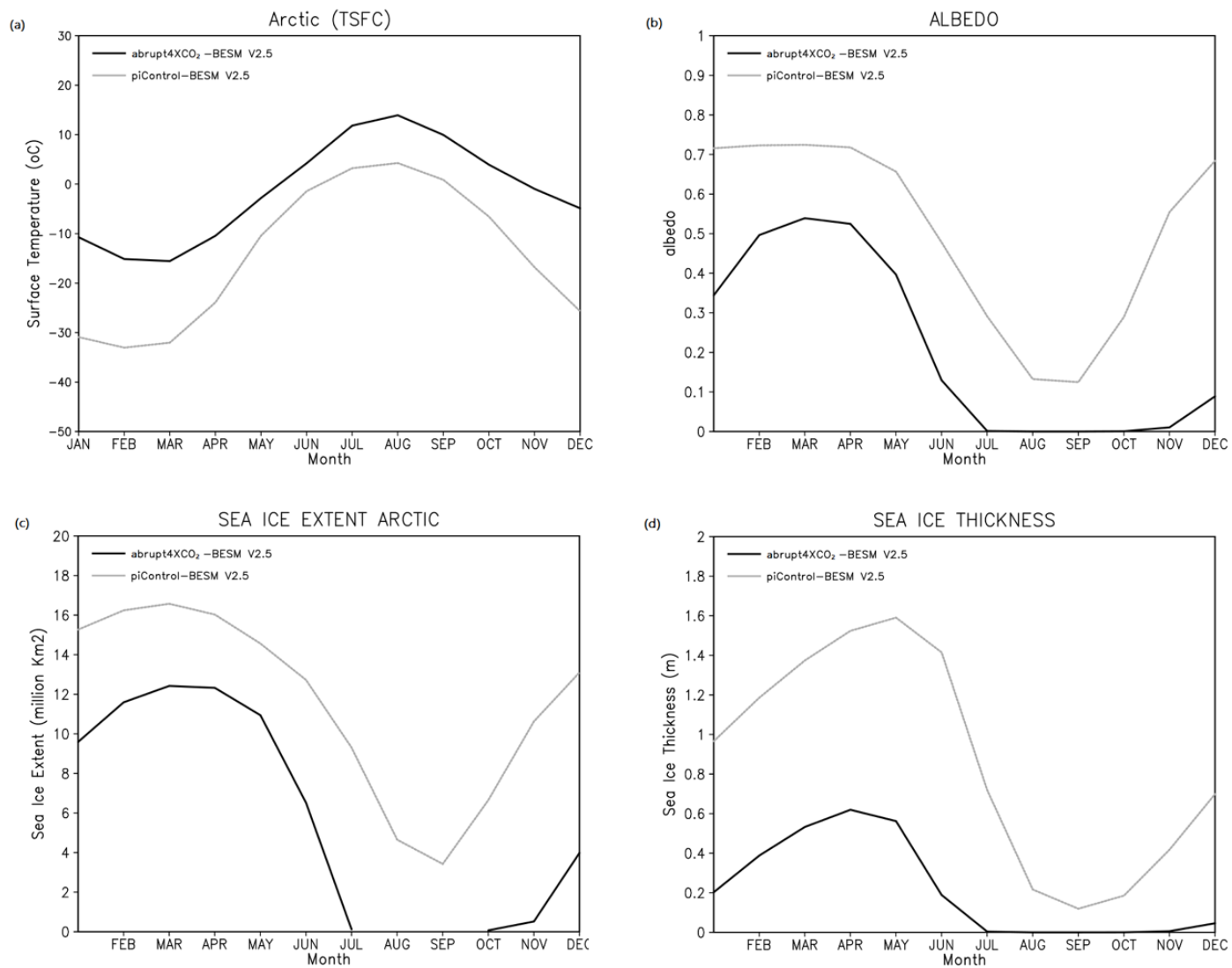

Source: authors' authorship (2021) 
The SIT simulated in both BESM-OA2.5 and the CMIP5 ensemble mean are too thin compared to observational data (no shown), resulting in enhanced melt and underestimation of summer SIE (Casagrande et al., 2016; Shu et al., 2015; Stroeve et al., 2012). Thin sea ice conditions in the control climate simulations typically resulted in amplified warming at $4 \mathrm{xCO}_{2}$ conditions, given that it is easier for sea ice to melt in a warmer climate (Rind et al., 1997; Rind et al., 1995). According to Rind et al. (1997), the climate sensitivity depends more on SIT than SIE from control climate simulations. Thus, we suggest that the enhanced polar warming present in BESM-OA2.5 and MPI-ESM-LR (Figure 1) is associated with thin sea ice piControl conditions presented in Figure 3.

The close relationship between sea ice loss and decrease in albedo results in an increase of heat exchanges between the ocean and atmosphere. This is because the high sea ice albedo (>0.7) reflects most of the incoming solar radiation back to space. When sea ice melts, the darker ocean (low albedo, $\sim 0.06$ ) is exposed to solar radiation and absorbs more energy, thus warming the ocean.

Winter albedo for piControl (abrupt $4 \mathrm{xCO}_{2}$ ) climate simulations varies from 0.69 to 0.72 (0.1 to 0.52$)$, which represents a significant increase of nearly $60 \%$ in energy absorption by the ocean in December. For summer the differences between piControl and abrupt $4 \mathrm{xCO}_{2}$ are lower since the SIE in piControl presents a small area of SIC (close to $3 \times 10^{6} \mathrm{~km}^{2}$ ).

The net energy fluxes are represented by the sum of net radiative fluxes (SW radiation from the sun and LW radiation emitted from the surface and by the atmosphere), sensible and latent fluxes (Bourassa et al., 2013). Freshwater fluxes into the ocean are due to precipitation, runoff and evaporation (P+R-E) (North et al, 2014; Stossel el al., 2011; Bourassa et al., 2013).

According to Bourassa et al. (2013) the latent heat flux is the rate at which energy associated with the phase change of water is transferred from the ocean to the atmosphere, the main terms related are wind speed and humidity. Similarly, the sensible heat flux is the rate at which thermal energy (associated with temperature, but without a phase change) is transferred from the ocean or sea ice to the atmosphere. The main terms are the difference between ocean and atmosphere and wind speed.

The response of the Arctic warming in heat fluxes (Sensible + Latent fluxes) over high northern latitudes is an increase for all seasons, stronger in winter (Figure 4a). The 
seasonal cycle simulated by piControl (abrupt $4 \mathrm{xCO}_{2}$ ) ranges are from approximately 10 $\mathrm{W} \cdot \mathrm{m}^{-2}$ in winter to $25 \mathrm{~W} \cdot \mathrm{m}^{-2}$ in summer. The large increases are found for the same period of strong Arctic warming (autumn and winter). The response of the Arctic warming to changes in Freshwater fluxes into the ocean (Precipitation minus Evaporation) over northern high latitude is an increase for all seasons, meaning that precipitation exceeds evaporation with an accentuated rise in summertime (Figure $4 \mathrm{~b}$ ). The Freshwater fluxes have a quite well-defined seasonal cycle. The piControl (abrupt $4 \mathrm{xCO}_{2}$ ) simulations vary from $10 \mathrm{~mm}(35 \mathrm{~mm})$ in winter to $45 \mathrm{~mm}(80 \mathrm{~mm})$ in summer (Figure $4 \mathrm{~b}$ ). According to Bintanja \& Selten (2014) the projected changes in precipitation over the Arctic Ocean as response to GHG forcing is more than $50 \%$. This marked increase is among the highest globally projected precipitation changes and is associated with enhanced poleward moisture transport from the lower latitudes (Kug et al., 2010).

Figure 4 - Seasonal cycle at northern high latitudes $\left(70^{\circ} \mathrm{N}-90^{\circ} \mathrm{N}\right)$ of (a) heat fluxes (sum of sensible and latent fluxes) and freshwater fluxes (precipitation - evaporation) for the last 30 years of quadrupling atmospheric $\mathrm{CO}_{2}$ numerical experiment compared to the last 30 years of the piControl run, using BESM-OA2.5.
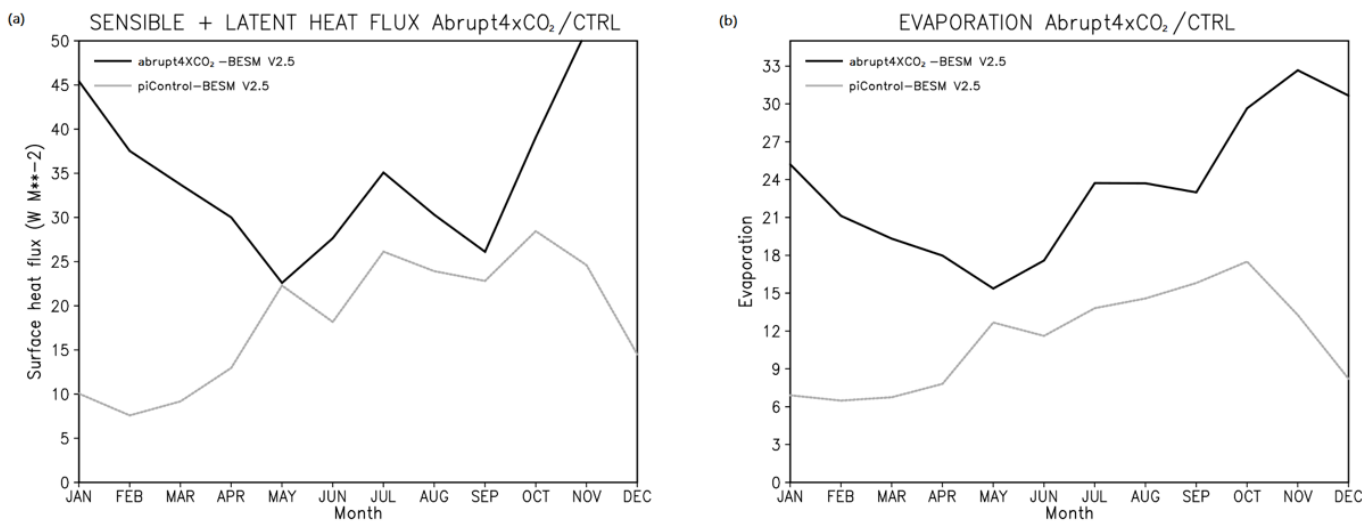

Source: authors' authorship (2021)

Feedback processes in the climate system may act to amplify or damp the initial radiative perturbation, such changes in $\mathrm{CO}_{2}$ concentration. The Radiative Kernel is a powerful technique used for calculating the climate feedbacks in Global Climate Models, allowing a robust analysis of climate sensitivity (Jonko et al., 2012; Soden et al., 2008). To quantify the feedback, the kernel is multiplied by the change in the variable interest (e.g albedo, temperature, cloud), typically normalized by the change in global mean 
surface temperature (SODEN et al., 2008). We applied the NCAR Radiative Kernel in BESM-OA2.5 for accesses the seasonal impact from different feedback mechanisms at northern high latitude (The Radiative Kernel NCAR are available in https://climatedataguide.ucar.edu/climate-data/radiative-kernels-climate-models.

Figure 5 - Climate feedbacks in BESM-OA2.5 for northern high latitudes $\left(70^{\circ} \mathrm{N}-90^{\circ} \mathrm{N}\right)$. Dashed (solid) lines represent the climate feedback for clear sky (all sky).

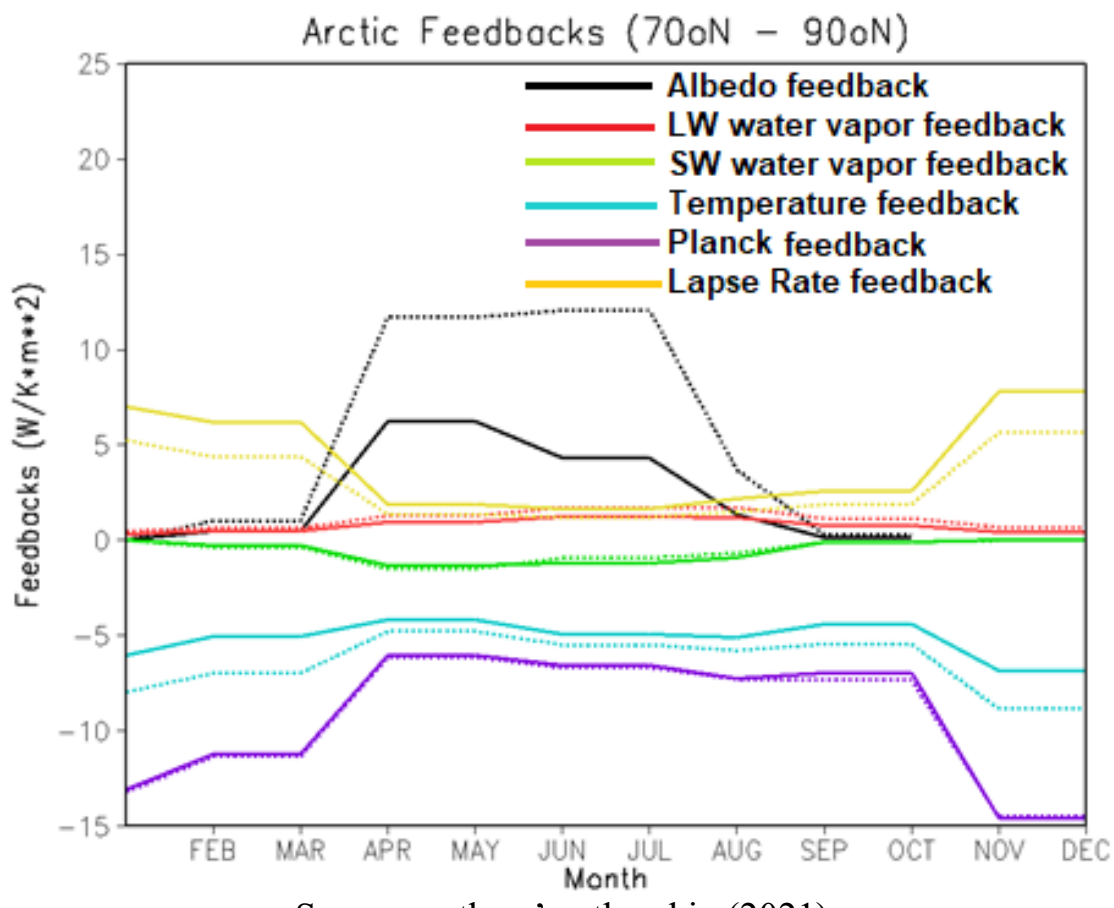

Source: authors' authorship (2021)

The Radiative Kernels presented below (Figure 5) were calculated for the water vapor, lapse rate, temperature and albedo feedback for both clear sky and all sky (Shell et al., 2008). Figure 5 shows the contribution of each feedback mechanism to the Arctic warming. Positive values are contributing to the Arctic warming while negative values are indicating cooling. The surface albedo feedback describes the response of downward shortwave radiation at the Top of the atmosphere (TOA) to a $1 \%$ additive rise in surface albedo (Soden et al., 2008). The large contribution of albedo feedback is evident from April to August with more accentuated values for clear sky. This result reinforces the simulated decrease in SIE and albedo for the same period presented in Figure 3. The water vapor feedback is not so evident because BESM-OA2.5 underestimated the cloud for northern high latitudes (Casagrande et al., 2016). Even so, water vapor feedback, associated with large changes in clouds is one of the most important climate feedbacks 
under global warming. From November to March the lapse rate feedback contributes for the Arctic warming and the planck feedback, in opposition contributes to a cooling (Figure 5).

\section{Conclusions}

We have examined the quadrupling of $\mathrm{CO}_{2}$ numerical experiment in order to assess the Arctic Climate sensitivity (through the Polar amplification) and the coupled ocean-atmosphere-sea ice processes associated. The amplified warming at high latitudes appears as an inherent characteristic of climate models with strongest warming in winter (DJF) and Autumn (SON), which exceeds the summer warming (JJA). The Arctic warming is linked with changes in SIE and SIT. The effects of abrupt $4 \mathrm{xCO}_{2}$ in sea ice is a sharp decrease in SIE and SIT followed by a decrease in annual amplitude, with outstanding ice-free conditions from July to October. In this scenario the Arctic Ocean will become covered only by first-year-sea ice (sea ice that does not survive to summer melt season). This thin sea ice is more vulnerable to melting away making the region more sensitive dynamically and thermodynamically to temperature changes and increasing the heat fluxes. The albedo sea ice feedback reinforces the polar warming with marked contributions from April to August for both all sky and clear sky. Future progress in the climate sensitivity and the polar amplification are essential to better understand the effects of climate changes in high latitudes and the related coupled ocean-atmosphere processes.

\section{ACKNOWLEDGEMENTS}

We are thankful to Brazilian agencies CNPq, CAPES and FAPERGS to the following projects: (i) National Institute for Science and Technology of the Cryosphere (CNPq 465680/2014-3 + FAPERGS 17/2551-0000518-0); (ii) Use and Development of the BESM Model for Studying the Ocean-Atmosphere-Cryosphere in high and medium latitudes (CAPES 88887-145668/2017-00); (iii) Development of the Brazilian Earth System Model - BESM and Generation of Climate Change Scenarios, Aiming at Impact Studies on Water Resources (CAPES 88887.123929/2015-00).

\section{REFERENCES}

ALEXEEV, V. A.; LANGEN, P. L.; BATES, J. R. Polar amplification of surface warming on an aquaplanet in "ghost forcing" experiments without sea ice feedbacks.

Clim. Dynamics, v.24, n.7-8, p.655-666, 2005. 
AMBAUM, M.; HOSKINS, B. J.; STEPHENSON, D. B. Arctic oscillation or North Atlantic oscillation? J. Clim., v.14, n.16, p.3495-3507, 2001.

BEKRYAEV, R. V.; POLYAKOV , I. V.; ALEXEEV, V. A. Role of polar amplification in long-term surface air temperature variations and modern Arctic warming. J. Clim., v.23, n.14, p.3888-3906, 2010.

BINTANJA, R.; VAN DER LINDEN, E. C. The changing seasonal climate in the Arctic. Scientific reports, v.3, 2013.

BINTANJA, R.; SELTEN, F. M. Future increases in Arctic precipitation linked to local evaporation and sea-ice retreat. Nature, v. 509, n. 7501, p. 479-482, 2014.

BOEKE, R. C.; TAYLOR, P. C.; SEJAS, S. A. On the Nature of the Arctic's Positive Lapse Rate Feedback. Geophys. Res. Lett, 48(1), e2020GL091109, 2021.

BOTTINO, M.; NOBRE, P. Impacts of Cloud Cover Schemes on the Atlantic Climate in the Brazilian Climate Model-BESM. "unpublished", 2015.

BOURASSA, M. A.; GILLE, S. T.; BITZ, C.; CEROVECKI, I.; et al. High-latitude Ocean and Sea Ice Surface Fluxes: Challenges for Climate Research. American Meteorological Society, v.94, p.403-423, 2013.

CAI, M. Dynamical amplification of polar warming. Geophys. Res. Lett, v.22, 2005. CAI, S., HSU, P. C.; LIU, F. Changes in polar amplification in response to increasing warming in CMIP6. 'Atmos. Ocean. Sci. Lett., 14(3), 100043, 2021.

CAI, Z. et al. Arctic warming revealed by multiple CMIP6 models: evaluation of historical simulations and quantification of future projection uncertainties. J. Clim., v. 34, n. 12, p. 4871-4892, 2021.

CASAGRANDE, F.; NOBRE, P.; SOUZA, R. B.; MARQUEZ, A. L.; TOURIGNY, E.; CAPISTRANO, V.; MELLO, R. L. Arctic sea ice: Decadal simulations and future scenarios using BESM-OA. Atmospheric and Clim. Sciences, 6(02), 351, 2016.

CASAGRANDE, F.; SOUZA, R. B.; NOBRE, P.; MARQUEZ, A. L. An interhemispheric seasonal comparison of polar amplification using radiative forcing of a quadrupling CO 2 experiment. In: Annales Geophysicae. Copernicus GmbH, p. 1123$1138,2020$.

CURRY, J.A.; SCHRAMM, J.L.; EBERT, E.E. Sea Ice Albedo Climate Feedback Mechanism. J. Clim., v.8, p.240-247, 1995.

DAI, A.; LUO, D.; SONG, M.; LIU, J. Arctic amplification is caused by sea-ice loss under increasing CO 2. Nature Communications, 10(1), 1-13, 2019.

DAVY, R.; OUTTEN, S. The Arctic surface climate in CMIP6: status and developments since CMIP5. J. Clim., 33(18), 8047-8068, 2020. 
DELWORTH, T.L.; BROCCOLI, A.J.; ROSATI, A.; Stouffer, R.J.; Balaji, V.; Beesley, J.A.; et al. GFDL's CM2 Global Coupled Climate Models. Part I: Formulation and Simulation Characteristics. J. Clim., v.19, p.643-674, 2006.

GENT, P.R.; DANABASOGLU, G.; DONNER, L.J.; HOLLAND, M.M.; HUNKE, E.C.; JAYNE, S.R., et al. The Community Climate System Model Version 4. J. Clim., v.24, p.4973-4991, 2011.

GOOSSE, H., et al. Quantifying climate feedbacks in polar regions. Nature Communications, 9(1), 1-13, 2018.

GRAVERSEN, R. G.; WANG, M. Polar Amplification in a Coupled Climate Model with Locked Albedo. Clim. Dynamics, v.33, n.5, p.629-643, 2009.

GRIFFIES, S.M. Elements of MOM4p1. NOAA/Geophysical Fluid Dynamics Laboratory Ocean Group Technical Report, n.6, p.444, 2009.

GRIFFIES, S.M.; WINTON, M.; DONNER, L.J.; HOROWITZ, L.W.; DOWNES, S.M.; FARNETI, R.; et al. The GFDL CM3 coupled climate model: characteristics of the ocean and sea ice simulations. J. Clim., v.24, p.3520-3544, 2011.

HALL, A. The role of surface albedo feedback in climate. J. Clim., v.17, n.7, p.15501568, 2004.

HOLLAND, M.M.; BITZ, C.M. Polar Amplification of Climate Change in the Coupled Model Intercomparison Project. Climate Dynamics, v.21, p.221-232, 2003.

HUNKE, E.C.; DUKOWICZ, J.K. An Elastic-Viscous-Plastic Model for Sea Ice Dynamics. Journal of Physical Oceanography, v.27, p.1849-1867, 1997.

HUUSKO, L. L.; BENDER, F. A.; EKMAN, A. M.; STORELVMO, T. Climate sensitivity indices and their relation with projected temperature change in CMIP6 models. Environ. Res. Lett., 2021.

IPCC, 2019: IPCC Special Report on the Ocean and Cryosphere in a Changing Climate [H.-O. Pörtner, D.C. Roberts, V. Masson-Delmotte, P. Zhai, M. Tignor, E. Poloczanska, K. Mintenbeck, A. Alegría, M. Nicolai, A. Okem, J. Petzold, B. Rama, N.M. Weyer (eds.)]. In press.

IPCC, 2021: Climate Change 2021: The Physical Science Basis. Contribution of Working Group I to the Sixth Assessment Report of the Intergovernmental Panel on Climate Change [Masson-Delmotte, V., P. Zhai, A. Pirani, S.L. Connors, C. Péan, S. Berger, N. Caud, Y. Chen, L. Goldfarb, M.I. Gomis, M. Huang, K. Leitzell, E. Lonnoy, J.B.R. Matthews, T.K. Maycock, T. Waterfield, O. Yelekçi, R. Yu, and B. Zhou (eds.)]. Cambridge University Press. In Press. 
JONKO, A. K., et al. Climate feedbacks in CCSM3 under changing CO2 forcing. Part I: Adapting the linear radiative kernel technique to feedback calculations for a broad range of forcings. J. Clim., v.25, n.15, p.5260-5272, 2012.

JUNG, E.; JEONG, J. H.; WOO, S. H.; KIM, B. M.; YOON, J. H.; LIM, G. H. Impacts of the Arctic-midlatitude teleconnection on wintertime seasonal climate forecasts.

Environ. Res. Lett., 15(9), 094045, 2020.

KUG, J. S.; et al. Role of synoptic eddy feedback on polar climate responses to the anthropogenic forcing. Geophys. Res. Lett, v.37, n.14, 2010.

LI, J. L.; XU, K. M.; JIANG, J. H.; LEE, W. L.; WANG, L. C.; YU, J. Y.; WANG, Y. H. An Overview of CMIP5 and CMIP6 Simulated Cloud Ice, Radiation Fields, Surface Wind Stress, Sea Surface Temperatures, and Precipitation Over Tropical and Subtropical Oceans. J. Geophys. Res. Atmos., 125(15), e2020JD032848, 2020.

LIU, Y.; et al. A cloudier Arctic expected with diminishing sea ice. Geophys. Res.

Lett, v.39, n.5, 2012.

MARSHALL, J.; et al. The ocean's role in polar climate change: asymmetric Arctic and Antarctic responses to greenhouse gas and ozone forcing. Phil. Trans. R. Soc.

A.3722013004020130040, v.372, n.2019, 2014.

MARSLAND, S.J.; HAAK, H.; JUNGCLAUS, J.H.; LATIF, M.; RÖSKE, F. The MaxPlanck-Institute Global Ocean/Sea Ice Model with Orthogonal Curvilinear Coordinates. Ocean Modelling, v.5, p.91-127, 2003.

NOBRE, P.; SIQUEIRA, L.S.; DE ALMEIDA, R.A.; MALAGUTTI, M.; GIAROLLA, E.; CASTELÃO, G.P.; et al. Climate Simulation and Change in the Brazilian Climate Model. J. Clim., v.26, p.6716-6732, 2013.

NORTH, G. R.; PYLE, J. A.; ZHANG, F. Encyclopedia of atmospheric sciences. Vol. 1. Elsevier, 2014.

NOTZ, D.; STROEVE, J. SIMIP Community, 2020: Arctic sea ice in CMIP6. Geophys. Res. Lett, 47, e2019GL086749, 2020.

O'NEILL, B. C., et al. The scenario model intercomparison project (ScenarioMIP) for CMIP6. Geosci. Model Dev., 9(9), 3461-3482, 2016.

OVERLAND, J.; DUNLEA, E.; BOX, J. E.; CORELL, R.; FORSIUS, M.; KATTSOV, V.; WANG, M. The urgency of Arctic change. Polar Science, 21, 6-13, 2019. PITHAN, F.; MAURITSEN, T. Arctic Amplification Dominated by Temperature Feedbacks in Contemporary Climate Models. Nature Geoscience, v.7, p.181-184, 2014.

SCREEN, J. A.; SIMMONDS, I. The central role of diminishing sea ice in recent Arctic temperature amplification. Nature, v.464, n.7293, p.1334-1337, 2010. 
SCREEN, J. A.; SIMMONDS, I. Increasing fall winter energy loss from the Arctic Ocean and its role in Arctic temperature amplification. Geophys. Res. Lett, v.37, n.16, 2010.

SCREEN, J. A.; WILLIAMSON, D. Ice-free Arctic at $1.5^{\circ}$ C?. Nature Climate Change, 7(4), 230-231, 2017.

SEMTNER, A.J. A Model for the Thermodynamic Growth of Sea Ice in Numerical Investigations of Climate. J. Phys. Oceanogr., v.6, p.27-37, 1976.

SERREZE, M. C.; FRANCIS, J. A. The Arctic amplification debate. Climatic change, v.76, p.241-264, 2006.

SERREZE, M. C.; et al. The Emergence of Surface-Based Arctic Amplification. The Cryosphere, v.3, p.11-19, 2009.

SERREZE, M. C; BARRY, R.G. Processes and Impacts of Arctic Amplification: A Research Synthesis. Global and Planetary Change, v.77, p.85-96, 2011.

SHELL, K. M.; KIEHL, J. T.; SHIELDS, C. A. Using the radiative kernel technique to calculate climate feedbacks in NCAR's Community Atmospheric Model. J. Clim., v.21, n.10, p.2269-2282, 2008.

SHEN, Z.; DUAN, A.; LI, D.; \& LI, J. Assessment and Ranking of Climate Models in Arctic Sea Ice Cover Simulation: From CMIP5 to CMIP6. J. Clim., 34(9), 3609-3627, 2021.

SHU, Q.; SONG, Z.; QIAO, F. Assessment of Sea Ice Simulations in the CMIP5 Models. The Cryosphere, v.9, p.399-409, 2015.

SHU, Q.; WANG, Q.; SONG, Z.; QIAO, F.; ZHAO, J.; CHU, M.; LI, X. Assessment of sea ice extent in CMIP6 with comparison to observations and CMIP5. Geophys. Res.

Lett, 47(9), e2020GL087965, 2020.

SMITH, D. M., et al. The Polar Amplification Model Intercomparison Project (PAMIP) contribution to CMIP6: investigating the causes and consequences of polar amplification, Geosci. Model Dev., 12, 1139-1164, 2019.

SODEN, B. J., et al. Quantifying climate feedbacks using radiative kernels. J. Clim., v.21, n.14, p.3504-3520, 2008.

STÖSSEL, A.; ZHANG, Z.; VIHMA, T. The Effect of Alternative Realtime Wind Forcing on Southern Ocean Sea Ice Simulations, J. Geophys. Res., v.116, p.1-19, 2011.

STROEVE, J.; HOLLAND, M.M.; MEIER, W.; SCAMBOS, T.; SERREZE, M. Arctic Sea Ice Decline: Faster than Forecast. Geophys. Res. Lett, v.34, L09501, 2007. 
STROEVE, J.; KATTSOV, V.; BARRETT, A.; SERREZE, M.; PAVLOVA, T.; HOLLAND, M.; MEIER, W.N. Trends in Arctic Sea Ice Extent from CMIP5, CMIP3 and Observations. Geophys. Res. Lett, v.39, L16502, 2012.

STUECKER, M. F., et al. Polar amplification dominated by local forcing and feedbacks, Nat. Clim. Change, 8, 1076-1081, 2018.

TAYLOR, K.E.; STOUFFER, R.J.; MEEHL, G.A. A Summary of the CMIP5 Experiment Design. CMIP Report, 30 p., 2009.

TAYLOR, K.E.; STOUFFER, R.J.; MEEHL, G.A. An Overview of CMIP5 and the Experiment Design. Bull. Amer. Meteor., v.93, p.485-498, 2012.

THACKERAY, C. W.; HALL, A. An emergent constraint on future Arctic sea-ice albedo feedback. Nature Climate Change, 9(12), 972-978, 2019.

VAVRUS, S. The Impact of Cloud Feedbacks on Arctic Climate under Greenhouse Forcing. J. Clim., v.17, n.3, p.603-615, 2004.

VEIGA, S. F.; NOBRE, P.; GIAROLLA, E.; CAPISTRANO, V.; BAPTISTA JR., M.; MARQUEZ, A. L.; FIGUEROA, S. N.; BONATTI, J. P.; KUBOTA, P.; NOBRE, C. A. The Brazilian Earth System Model ocean-atmosphere (BESM-OA) version 2.5: evaluation of its CMIP5 historical simulation, Geosci. Model Dev., 12, 1613-1642, 2019.

WEI, J.; WANG, Z.; GU, M.; LUO, J. J.; WANG, Y. An evaluation of the Arctic clouds and surface radiative fluxes in CMIP6 models. Acta Oceanologica Sinica, 40(1), 85$102,2021$.

WILD, M. The global energy balance as represented in CMIP6 climate models. Climate Dynamics, 55, 553-577, 2020.

WINTON, M. A Reformulated Three-Layer Sea Ice Model. J. Atmos. Ocean. Technol., v.17, p.525-531, 2000.

\section{Recebido em: 01/10/2021}

Aprovado em: 30/10/2021 